\title{
PRINCIPAL EARTHQUAKES IN NEW ZEALAND IN 1992
}

\author{
Warwick D. Smith 1
}

\begin{abstract}
The pattern of earthquakes in New Zealand during 1992 was a little unusual, in that the latter half of the year was very quiet. There were 13 shocks of magnitude 5.0 or greater during the year: only four of these were in the July-December period, the largest only 5.4. In contrast, the nine shocks in the first half of the year included one of magnitude 6.4 and four others of 5.5 or greater.
\end{abstract}

The largest earthquake of the year occurred on 28 May, and was centred $30 \mathrm{~km}$ south-west of Blenheim. Its magnitude was 6.4 , larger than those in March 1987 near Edgecumbe in the Bay of Plenty (6.1) and in May 1990 near Dannevirke (6.2). However the effects were not as severe as either of these, because the focal depth was $84 \mathrm{~km}$. The earthquake was felt from Huntly in the north to Dunedin in the south, most strongly in Nelson and Blenheim where many shops had goods thrown from shelves and there were some instances of minor damage. Intensity MM VI has been assigned in those two localities.

Tall buildings in Wellington swayed for at least a minute. A more surprising report came from the Awatere Valley, indicating that the earthquake was "barely felt" there. It seems that this particular location was close to a node of the radiation pattern from the focus, so ground motion was very modest compared with that in Blenheim, not far away.

On March 2 there was an earthquake of magnitude 5.5 in southern Hawke's Bay, between Weber and Porangahau, then another on August 1, of magnitude 5.2 and centred between Weber and Pahiatua. Intensities reached MM V on March 2 and MM IV on August 1. These shocks appear to have been part of the continuing Weber sequence, which began with two in 1990 February and May, causing damage in Dannevirke and the nearby area. The sequence has continued since then, but mostly at a low level with only the occasional shock being felt. This sequence is somewhat unusual in its length, especially as the 1992 events were two years after the main shock. The Observatory is continuing surveillance of the area with its permanent network of seismographs.
Other shallow earthquakes of magnitude 5.0 and greater occurred near White Island on March 26 (5.4), and June 22 $(5.6,5.1)$, all felt strongly in Tauranga (maximum intensity MM VI); near Arthur's Pass on March 30 (mag. 5.5, maximum intensity MM V); and near Tokomaru Bay on the East Coast on May 17 (mag. 5.3, maximum intensity MM V).

Deep earthquakes exceeding magnitude 5.0 occurred near Te Kuiti at a depth of $233 \mathrm{~km}$ on January $15(5.1), 30 \mathrm{~km}$ southwest of Hawera at $122 \mathrm{~km}$ on February 18 (5.5), $296 \mathrm{~km}$ deep below Tauranga on August 10 (5.1), $167 \mathrm{~km}$ below Rotorua on September 29 (5.2), and $167 \mathrm{~km}$ deep, just west of National Park on December 12 (5.4). None of these caused intensities exceeding MM IV, because of their focal depths.

The paucity of earthquakes in the latter half of the year is interesting. There is of course little or no regularity in the pattern of earthquake occurrence, and while long-term average rates have been established, the variation about these averages is quite substantial. So no particular significance can be attached to the quiet period. It is true that periods of quiescence have been observed before large earthquakes, but this phenomenon is not well understood and there are no grounds for assuming that this current quiet period is anything more than an illustration of the sporadic nature of earthquakes.

${ }^{1}$ Institute of Geological \& Earth Sciences, Wellington. (Fellow) 